\title{
A PERÍCIA FORENSE E A ANÁLISE DE VESTíGIOS EM LOCAIS DE CRIME
}

Laila Cristina Rodrigues Silva, Fábio Ferreira Morong, Celia dos Santos Silva

Universidade do Oeste Paulista - UNOESTE. Presidente Prudente, SP.

\section{RESUMO}

A Perícia Forense é responsável por preservar e analisar os vestígios deixados em determinado local em razão de uma prática delituosa. É essencial, pois tais vestígios poderão ser os únicos elementos existentes para a solução do crime praticado, com a identificação do agente e os detalhes da execução de tal delito. Pretende-se demonstrar a importância da Perícia Forense na apuração e elucidação de crimes, analisando sua relevância e destacando a responsabilidade e atribuições inerentes aos profissionais responsáveis pela construção do laudo técnico-pericial, bem como discorrer acerca da preservação dos interesses maiores da coletividade, com a efetiva resolução dos crimes, impedindo a impunidade. O método aplicado foi o dedutivo legal com a análise da doutrina, legislação nacional e jurisprudência pertinente ao tema. Conclui-se que a concretização da perícia forense proporciona subsídios para um julgamento justo, garantindo, assim, a justiça, paz e a ordem social.

Palavras-chave: Perícia Forense. Vestígios. Local do crime. Resolução de crimes.

\section{THE FORENSIC EXPERTISE AND THE ANALYSIS OF THE TRACES IN CRIME LOCATIONS.}

\begin{abstract}
The Forensic Expertise is responsible for preserving and analyzing the traces left in certain place, in reason of to a criminal practice. It's essential, because that traces could be the only have elements for the solution of the crime practiced, with identification of the agent and the details of the execution of that crime. Intended-it to demonstrate the importance of the Expertise Forensic, in the investigation and elucidation of crimes, analyzing your relevance and, highlighting the responsibility and attributions, of the technical expert report, as well as discussing the larger interests of the community, with a resolution of crimes, preventing the impunity. The research applied was the legal deductive with the analysis of the doctrine, national legislation and jurisprudence pertaining to the subject. It's concluded that the realization of Forensic Expertise provides grants for a fair trial, thus guaranteeing justice, peace and social order.
\end{abstract}

Keywords: Forensic Expertise. Traces. Crime location. Resolution of crimes. 


\section{INTRODUÇÃO}

A Perícia Forense é responsável por analisar os vestígios deixados, em determinado local, após uma prática delituosa, de maneira que a expressão "local do crime" é utilizada para demonstrar qualquer lugar físico do incidente, onde tenha ocorrido algum tipo de registro da ação anterior.

Com efeito, todo crime praticado, seja contra uma pessoa ou mesmo patrimônio, irá deixar, mesmo que em nível microscópico, uma troca no ambiente no qual é praticado. Ademais, tal troca se dará no referido ambiente, entre o agressor e o bem jurídico tutelado e, serão chamados de "vestígios".

Desta forma, a necessidade de coleta desses vestígios, bem como, a sua análise, é reproduzir, de forma fiel e incontestável, o "modus operandi", do crime em questão.

Portanto, é necessário que, a Perícia Forense se valha de todos os melhores conhecimentos técnicos necessários, para ser efetiva e, conseguir elucidar o crime praticado.

Logo, o objetivo geral, do presente artigo, é estabelecer o papel, da Perícia Forense na análise de vestígios em locais de crime, pontuando a relevância que os vestígios têm na apuração e elucidação das práticas delituosas, além de destacar a responsabilidade e as atribuições que cabem aos profissionais responsáveis pela construção do laudo técnico-pericial.

Por fim, cabe ainda expor a importância da Perícia Forense para garantir a paz e a ordem social, ao permitir a identificação dos agentes criminosos.

\section{METODOLOGIA}

Para elaboração do presente trabalho utilizou-se da metodologia da pesquisa bibliográfica, utilizando materiais como doutrinas, legislação nacional e jurisprudências, que são pertinentes para o objeto em estudo. O método dedutivo também fora utilizado para sistematizar os dados coletados a fim de cumprir o objetivo proposto.

\section{RESULTADOS E DISCUSSÃO}

Após a ocorrência de uma prática delituosa, serão encontrados no local da mesma, elementos materiais para a resolução do ocorrido, desde a identificação do agente, até o seu "modus operandi", além de prováveis vestígios de impressões digitais, pegadas, fios de cabelo, etc.".

Ressalte-se que, inclusive, o "modus operandi" do agente importa na resolução do crime pois, é de acordo com o mesmo que será definida a presença ou não, de circunstâncias atenuantes ou agravantes, dentre outras, em eventual dosimetria da pena.

Conforme leciona Santiago (2014, p. 22):

a investigação objetiva, por seu turno, volta a sua atenção para as evidências materiais do fato, preocupando-se com a busca de informações de cunho técnico científico. Ficando patente, por conseguinte, "ser o vestígio a matéria-prima a ser explorada pelos peritos, tornando-se peça fundamental no oferecimento da materialidade do evento".

Todavia, tais vestígios deixados são muito frágeis e passíveis de fácil alteração, seja pela ausência da preservação correta, decurso do tempo ou, até mesmo, eventual manipulação.

Segundo Mallmith (2007, p. 48), os vestígios são definidos como:

Os vestígios constituem-se, pois, em qualquer marca, objeto ou sinal sensível que possa ter relação com o fato investigado. A existência do vestígio pressupõe a existência de um agente provocador (que o causou ou contribuiu para tanto) e de um suporte adequado para a sua ocorrência (local em que o vestígio se materializou). 
Desta forma, se faz necessário o isolamento do local do crime, conforme assevera Ludwing (1995, p 32):

Isso significa que, para preservar os vestígios da infração, o local deve ser isolado, isto é, separado da interferência de pessoas não-credenciadas, de animais e de fenômenos naturais. É uma medida muito importante, pois a autoridade encarregada das investigações, e os técnicos por ela requisitados, precisam do local tal como foi deixado após a ocorrência delituosa. Caso contrário, terá que ser declarado inidôneo o local, embora não seja motivo para o não exame.

Portanto, é certo que os vestígios deixados no local do crime são de suma importância para a resolução do caso; também, é inequívoco que tais vestígios necessitam de preservação apropriada, o mais rápido possível, afim de garantir a sua integridade, preservando-se todos os elementos possíveis.

De outro lado, a resolução do caso depende, também, do estado da evidência física, no momento em que a mesma é coletada. Assim, afim de que haja eficaz preservação do local de crime, se faz mister cuidado especial com todos os vestígios encontrados, para que não sejam perdidos ou deteriorados.

Destarte, para que ocorra essa correta preservação do local do crime, se faz necessário o procedimento de isolamento citado.

Outrossim, faz parte do procedimento de preservação do local de crime a vigilância das autoridades policiais, com o intuito de impedir a entrada de pessoas no local, bem como, a alterações por agentes naturais, tais como a chuva, ventanias e outros fatores.

Nesse sentido, o artigo 60, incisos I, II e III, do Código de Processo Penal, determina:

Artigo 60: I - se possível e conveniente, dirigir-se ao local, providenciando para que se não alterem o estado e conservação das coisas, enquanto necessário;

I - dirigir-se ao local

II - apreender os objetos que tiverem relação com o fato, após liberados pelos peritos criminais;

III - colher todas as provas que servirem para o esclarecimento do fato e suas circunstâncias;

IV - ouvir o ofendido; $V$ - ouvir o indiciado;

$\mathrm{VI}$ - proceder a reconhecimento de pessoas e coisas e a acareações; VIII - ordenar a identificação do indiciado pelo processo datiloscópico, se possível, e fazer juntar aos autos sua folha de antecedentes;

IX - averiguar a vida pregressa do indiciado (BRASIL, 1941);

Portanto, extrai-se que há de ser todo o esforço necessário, para que não haja modificação das provas, e a situação do local do crime seja avaliada corretamente. Também, é importante dispensar atenção ao chão, no local do crime, pois, comumente, são encontrados vestígios da prática delituosa, no mesmo, e, tal evidência, apresenta alto potencial de contaminação.

Ademais, igualmente é relevante ressaltar que o cuidado nas ações iniciais também é fator fundamental para a admissibilidade das evidências.

Por sua vez, Dinamarco (2002, p. 51) esclarece que:

Provas ilícitas são as demonstrações de fatos obtidas por modos contrários ao direito, quer no tocante às fontes de prova, quer quanto aos meios probatórios. A prova será ilícita - ou seja, antijurídica e, portanto, ineficaz a demonstração feita - quando o acesso à fonte probatória tiver sido obtido de modo ilegal ou quando a utilização da fonte se fizer por modos ilegais. Ilicitude da prova, portanto, é ilicitude na obtenção das fontes ou ilicitude na aplicação dos meios. 
Em relação ao primeiro profissional envolvido na investigação a chegar ao local, o mesmo deverá manter o isolamento adequado, até a chegada do profissional responsável pela realização da Perícia Forense.

Nesta senda, o conteúdo da norma processual penal assim se apresenta:

Art. 169. Para o efeito de exame do local onde houver sido praticada a infração, a autoridade providenciará imediatamente para que não se altere o estado das coisas até a chegada dos peritos, que poderão instruir seus laudos com fotografias, desenhos ou esquemas elucidativos. (Vide Lei no 5.970, de 1973).

Parágrafo único. Os peritos registrarão, no laudo, as alterações do estado das coisas e discutirão, no relatório, as consequências dessas alterações na dinâmica dos fatos. (Incluído pela Lei no 8.862, de 28.3.1994). (BRASIL, 1941)

Logo, o sucesso da Perícia Forense e, consequentemente, o sucesso de toda a investigação criminal, depende da eficaz preservação do local do crime.

Ressalte-se que, no local de crime, serão pesquisados elementos físicos que configurarão as provas materiais para a tipificação do delito. Desta forma, o cuidado e o respeito à legalidade dos procedimentos necessários hão de ser metas do perito forense, uma vez que, todas as provas devem ser obtidas de modo lícito.

Conforme explica Santiago (2014, p. 22):

a investigação objetiva, por seu turno, volta a sua atenção para as evidências materiais do fato, preocupando-se com a busca de informações de cunho técnico científico. Ficando patente, por conseguinte, "ser o vestígio a matéria-prima a ser explorada pelos peritos, tornando-se peça fundamental no oferecimento da materialidade do evento.

Assim sendo, percebe-se a relevância da preservação dos vestígios deixados no local do crime, com a realização dos corretos procedimentos de isolamento e preservação do local de crime, para a ocorrência de um trabalho pericial que proporcione a máxima exatidão, quanto a análise desses vestígios, eliminando a possibilidade de conclusões conflitantes.

Por conseguinte, autoridades envolvidas na resolução dos crimes possuem total interesse em sua resolução, diante de todo o material probatório que fornecerá, por meio do laudo técnico pericial.

Zarzuela (2000, p. 35) ensina que:

Consiste na exposição minuciosa, circunstanciada, fundamentada e ordenada das apreciações e interpretações realizadas pelos Peritos, com a pormenorizada enumeração e caracterização dos elementos materiais encontrados no local do fato, no instrumento do crime, na peça de exames e na pessoa física, viva ou morta. Apresenta a perícia e, consequentemente, sua materialização instrumental, isto é, o laudo pericial, a peculiaridade de ser uma função estatal destinada a fornecer dados instrutórios e formação do corpo de delito [...]

Em suma, é a materialização desses vestígios que compõe o conjunto de peças do inquérito policial.

Por sua vez, no que diz respeito aos beneficiários da perícia forense, explana doutrina que:

Os beneficiários da perícia são aqueles que de alguma forma se beneficiam do serviço. A sociedade como um todo tem interesse em uma Justiça Criminal que encontre e puna os responsáveis por delitos cometidos (ou inocente aqueles erroneamente acusados), e ao mesmo tempo respeite os direitos humanos. A perícia contribui para este anseio da sociedade com provas científicas que ajudam a Polícia e a Justiça Criminal, respectivamente, a identificar e julgar os verdadeiros autores dos delitos (RODRIGUES; SILVA; TRUZZI, 2010, p. 848).

Ainda, nos dias atuais, é importantíssimo valer-se dos avanços tecnológicos, conforme explica Queiroz (2004, p. 287): 
Partindo-se, então, da premissa de que, nessa reconstituição, os recursos da Informática devem ser objeto de alcance e emprego científico na busca da verdade, e que a cognição de indícios, locais de crimes e outras circunstâncias, podem ser carreadas para os autos como um fator de correta interpretação da materialidade e da autoria, surgiu a ideia de que a vivência da autoridade policial, enquanto pesquisador da criminalidade, pode ser resumida graficamente em uma única peça documental, que traduz o acompanhamento de circunstâncias e de fatos, desde a motivação do crime até o seu desfecho. Esse método, em si mesmo, é conhecido doutrinariamente, como cognição visuográfica de local de crime. Além do que, interessa a toda a coletividade que não haja a impunidade, para a preservação de seus interesses, ou seja, a garantia da paz e ordem social.

Logo, é inequívoco que há uma intrínseca relação entre a colheita adequada dos vestígios existentes no local do crime e a sua análise, com a elucidação do mesmo e, a consequente preservação dos interesses de toda a sociedade.

Nesse sentido, conforme Rodrigues, Silva e Truzzi (2010), no Estado Democrático de Direito, é preciso conciliar o respeito aos direitos humanos com uma investigação eficaz dos crimes, de forma a levar os seus autores às barras dos tribunais e propiciar um julgamento justo.

Inclusive, é importantíssimo salientar a enorme responsabilidade que recai sobre os profissionais responsáveis pela construção do laudo técnico-pericial, já que, no que diz respeito à mobilização do Estado, para a elucidação das condutas criminosas praticadas, a Perícia Forense figura como uma das três vias concomitantes. De acordo com Oliveira:

A atuação das forças policiais no combate ao crime no Brasil dá-se de um modo geral em três vias concomitantes: 1) o policiamento ostensivo, realizado pelas forças policiais militares de cada Estado, o qual compreende o confronto físico direto com os criminosos; 2) a investigação policial, realizada pela polícia civil; 3) a pesquisa de vestígios em cenas de crime, realizada pela polícia científica (OLIVEIRA, 2006, p. 17). (grifos nossos).

Além disso, a responsabilidade de tais profissionais repousa na realização da correta associação dos vestígios materiais encontrados no local do crime, com o agente suspeito e a eventual vítima.

De outro lado, é claro que o próprio laudo técnico pericial que possibilita a identificação dos agentes, e conforme elucida Silva:

O perito criminal, no desempenho de suas funções, em diversas situações entra em contato com materiais biológicos que podem possibilitar a extração de DNA, auxiliando ou até mesmo sendo decisivo em seus exames periciais e contribuindo para a resolução do crime. Quando a amostra biológica é corretamente coletada e preservada, o DNA pode permanecer por vários anos em condições de estudo. Isto permite que pessoas envolvidas em crimes sejam inocentadas ou incriminadas após o evento (SILVA, 2006, p. 15).

Logo, é a análise dos vestígios presentes no local do crime o elemento primordial para determinar que, embora investigadas, tais pessoas não estão envolvidas em determinado crime.

\section{CONCLUSÃO}

Salienta-se que, por vezes, os vestígios existentes no local do crime são os únicos elementos que apontam o que realmente ocorreu.

Portanto, a preservação dos vestígios deixados pelo crime, bem como, a sua análise, são essenciais, a fim de evitar a impunidade, que ocorrerá caso o crime não venha a ser solucionado.

Ainda, por sua vez, restou clara a intrínseca relação entre a colheita adequada dos vestígios existentes no local do crime e a sua análise, com a elucidação do mesmo e, a consequente preservação dos interesses de toda a sociedade. 
Assim sendo, o papel do perito forense é de extrema importância, pois é de interesse de toda a coletividade que, os agentes criminosos sejam responsabilizados, para a garantia da paz e ordem social.

Portanto, conclui-se que a Perícia Forense tem como função viabilizar de forma precisa a identificação dos agentes, locais e vestígios envolvidos, e consequentemente, por meio de sua concretização, proporcionar subsídios para uma decisão justa, garantindo, assim, a justiça, paz e a ordem social.

\section{REFERÊNCIAS}

BRASIL. Decreto-Lei n 3.689 de 03 de outubro de 1941. Institui o Código de Processo Penal. Diário Oficial da República Federativa do Brasil, Rio de Janeiro, 04 de outubro de 1941.

DINAMARCO, Cândido Rangel. Instituições de Direito Processual Civil. 2ª ed. São Paulo: Malheiros, 2002, 2v.

GERHARDT, Tatiana; SILVEIRA, Denise. Métodos de pesquisa. Coordenado pela Universidade Aberta do Brasil - UAB/UFRGS e pelo Curso de Graduação Tecnológica - Planejamento e Gestão para o Desenvolvimento Rural da SEAD/UFRGS. - Porto Alegre: Editora da UFRGS, 2009. Disponível em: <http://www.ufrgs.br/cursopgdr/downloadsSerie/derad005.pdf>. Acesso em: 05 jul. 2018.

SANTIAGO, Elizeu. Criminalística comentada: exposição e comentários de temas periciais e assuntos correlatos: questões polêmicas: temas controvertidos. 1 ed. Campinas, SP: Millennium Editora, 2014.

LARA, Alexandre Guilherme da; FARIA, Rubens Alexandre de. Análise Forense de Microvestígios: fios de cabelo. XXIV Congresso Brasileiro de Engenharia Biomédica - CBEB 2014. Disponível em: <http://www.canal6.com.br/cbeb/2014/artigos/cbeb2014_submission_201.pdf>. Acesso em: 05 jul. 2018.

LUDWIG, Artulino. A Perícia em Local de Crime. Rio Grande do Sul: Ed. da UBRA, 1996.

MALLMITH, Décio de Moura. Local de crime. 3.ed. Porto Alegre: Luzes, 2007.

OLIVEIRA, Marcelo Firmino de. Química Forense: a utilização da química na pesquisa de vestígios de crime. Química Nova Escola. n. 24, novembro de 2006. Disponível em: <http://qnesc.sbq.org.br/online/qnesc24/ccd2.pdf>. Acesso em: 05 jul. 2018.

QUEIROZ, Carlos Alberto Marchi de. Manual de polícia judiciária. 3.ed. São Paulo: São Paulo, 2004.

RODRIGUES, Cláudio Vilela; SILVA, Márcia Terra da; TRUZZI, Oswaldo Mário Serra. Perícia Criminal: uma abordagem de serviços. Gest. Prod., São Carlos, v. 17, n. 4, p. 843-857, 2010. Disponível em: <http://www.scielo.br/pdf/gp/v17n4/a16v17n4>. Acesso em: 05 jul. 2018.

SANTIAGO, Elizeu. Criminalística comentada: exposição e comentários de temas periciais e assuntos correlatos: questões polêmicas: temas controvertidos. 1 ed. Campinas, SP: Millennium Editora, 2014. 
SILVA, Luiz Antonio Ferreira da. DNA Forense: coleta de amostras biológicas em locais de crime para estudo do DNA. 2.ed. Maceió: EdUFAL, 2006.

VASQUES, Paulo Maurício. Medicina Legal: curso e concursos: com questões de concursos. Rio de Janeiro: Freitas Bastos, 2015.

ZARZUELA, José Lopes. Laudo Pericial - Aspectos Técnicos e Jurídicos. Porto Alegre: Revista dos Tribunais, 2000. 